\title{
Exploring the Items for Measuring e-Procurement Usage Construct: An Exploratory Factor Analysis
}

Suhaidi Elias, Veera Pandiyan A/L Kaliani Sundram and Noriah Ismail

To Link this Article: http://dx.doi.org/10.6007/IJARBSS/v10-i12/8164

DOI:10.6007/IJARBSS/v10-i12/8164

Received: 01 November 2020, Revised: 27 November 2020, Accepted: 17 December 2020

Published Online: 26 December 2020

In-Text Citation: (Elias et al., 2020)

To Cite this Article: Elias, S., Sundram, V. P. A. K., \& Ismail, N. (2020). Exploring the Items for Measuring eProcurement Usage Construct: An Exploratory Factor Analysis. International Journal of Academic Research in Business and Social Sciences, 10(12), 822-837.

\section{Copyright: (c) 2020 The Author(s)}

Published by Human Resource Management Academic Research Society (www.hrmars.com)

This article is published under the Creative Commons Attribution (CC BY 4.0) license. Anyone may reproduce, distribute, translate and create derivative works of this article (for both commercial and non-commercial purposes), subject to full attribution to the original publication and authors. The full terms of this license may be seen at: http://creativecommons.org/licences/by/4.0/legalcode

\section{Vol. 10, No. 12, 2020, Pg. 822 - 837}

Full Terms \& Conditions of access and use can be found at http://hrmars.com/index.php/pages/detail/publication-ethics 


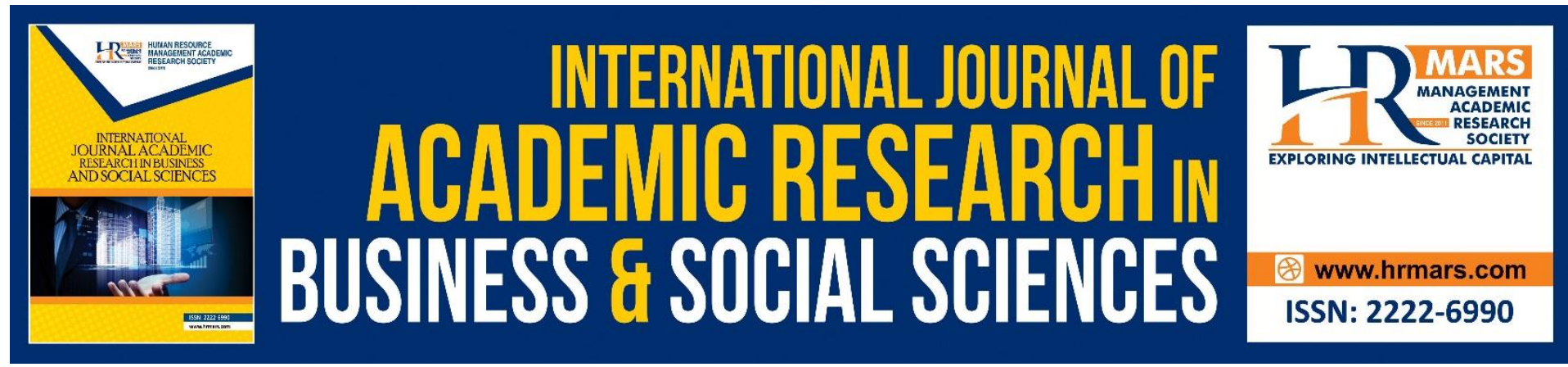

\title{
Exploring the Items for Measuring e-Procurement Usage Construct: An Exploratory Factor Analysis
}

\author{
Suhaidi Elias ${ }^{1}$, Veera Pandiyan A/L Kaliani Sundram ${ }^{2}$ and \\ Noriah Ismail ${ }^{3}$ \\ 1, ${ }^{2}$ Faculty of Business and Management, Universiti Teknologi MARA, Cawangan Johor, \\ Malaysia, ${ }^{3}$ Academy of Language Study, Universiti Teknologi MARA, Cawangan Johor, \\ Malaysia \\ Email: suhaidi27@uitm.edu.my, veera692@uitm.edu.my,noriah135@uitm.edu.my
}

\begin{abstract}
The usage of Information system (IS) in any institution is vital and this human technology interaction is the heart of many world-changing endeavors. The aim of this research is to perform instrument validation through exploratory factor analysis (EFA) of using eprocurement. The questionnaire used in this study is adapted from two different studies: Venkatesh et al., (2012) and Norzaidi (2008). It consists of five sub-constructs; after the questionnaire was distributed, 115 responses were collected to do the EFA. EFA was done for each construct separately. The results show that all of the seven constructs have one component or dimension, the factor loading for every item in each construct is $>0.6$, Bartlett's Test of Sphericity was $<0.05$ for all the constructs, which is Significant (P-value $<0.05$ ). Kaiser-Meyer-Olkin Measure of Sampling Adequacy was higher than 0.6 for all the constructs, and this means that the sample size is adequate. Cronbach's Alpha test was higher than 0.7 for the entire constructs' items, which means that these items are all reliable. This study found a valid and reliable instrument for measuring the usage of e-procurement to Malaysian contractors'.
\end{abstract}

Keywords: Exploratory Factor Analysis, Information System, E-Procurement Usage

\section{Introduction}

E-procurement is the use of integrated information technology for part of or all the procurement functions, from the beginning to end, i.e. from searching, sourcing, negotiating, ordering, and receipt to post-purchase review (Croom \& Jones., 2005; Trkman \& McCormack, 2010). E-procurement has been recently receiving much attention from businesses, industries, and governments as it reportedly becomes a powerful tool to improve effectiveness and efficiencies as well as the service quality of its adopters.

Malaysian government procurement is perceived as a major function of government and a substantial amount of money is allocated annually for the procurement of goods and services (Thai, 2001; Maniam et al., 2009). The Malaysian government spends more than RM150 billion every year in procuring goods, works and services and this gives a sign of riskiness of public procurement being exposed to corruption (Ministry of Finance, 2011). AG 
Report for years 2012 and 2013 highlighted that most of the cases reported in the government agencies were associated with the procurement.

\section{Literature Review}

The Malaysian government embarked on the e-Procurement or specifically e-perolehan project in 1999 to transform the public procurement landscape. Since Malaysian government is a major purchaser of supplies and services from the private sector spending a total of RM35 billion annually, e-Procurement is seen to be an effective tool of ensuring value for money as well as transparency and accountability in the public procurement process (Maniam et al., 2010).

The exercise of e-Procurement has been developed in stages to allow the suppliers particularly small-scale companies to adapt themselves with the new changes in the procurement system. The initial stage of implementation of e-Procurement starts with the launching of two Modules that is the 'Procurement via Central Contract' and the 'Suppliers Registration' on October 6, 2000. This was followed by the launching of the 'Direct Purchase module' on May 10, 2002. The module for tender and quotation was the last module developed under the e-Procurement system.

The 'e-Procurement' application enables the suppliers to display and introduce their products and services virtually over the internet 24 hours a day. In addition, the application also accommodates the procurement transactions from the initial stage of the procuring process to the final stage which involves payments to the suppliers and contractors. Among of the e-Procurement, applications are e-Perolehan, MyProcurement, Direct Tender, and eConstruction.

As of May 2006, there were 115,000 suppliers registered under the e-Procurement system in Malaysia (Harian, 2006). To date, the e-Procurement system had generated revenue of RM 1.08 billion from 107,000 transactions (Harian, 2006). The government issued a directive TCL 5/2003 instructing all the e-procurement enabled government agencies to execute procurement transactions through the central contract and direct purchases on-line. Contractors, on the other hand, need to register under the Contractors Service Centre (CSC) or Construction Industry Development Board (CIDB) before they can proceed with government procurement.

Even though construction is mainly a service industry, most of its activities require material handling and assembly functions. E-Procurement is critical to construction because it involves a number of partners on each project who all have the need for inventory management in order not to delay the project or to tie space and money on excess inventory while also complying with specifications and other variables (Pheng \& Meng, 1997). Beyond the obvious transaction cost savings and access to suppliers, e-Procurement can offer product standardization, quality assurance, inventory management and the opportunity to manage material flows down the value chain (i.e. the contractor having input in subcontractors' choices, the owner having input in contractors' choices, etc.).

The best practices of the procurement processes in the construction industry are based on searching for vendor databases and comparing the products based on relevant technical and cost factors as well as detailed, uniformed, standard documentation (Opentext News, 2001). Sanders et al., (2001, cited in Issa et al., 2003) determined that e-Procurement saves up to fifteen percent (15\%) of the total purchase cost. It lowers the internal requisitioning cost by automating the internal requisitioning process. Companies reduce personnel costs and time inefficiencies with requisition approval and order processing. E- 
Procurement automates the workflow of procurement/resource management processes, which reduces the cycle time of purchases, decreases stocking requirements, and lowers inventory management costs. Finally, e-Procurement applications enable enterprises to manage long-term relationships with suppliers. These relationships can be leveraged to create an enterprise-wide buying environment with the most favorable conditions.

\section{Significance of the Study}

Understanding factors as part of the cause of the system usage has become greater doubt in the field of Information System (IS). E-procurement is the use of integrated information technology for part of or all the procurement functions, from the beginning to end, i.e. from searching, sourcing, negotiating, ordering, and receipt to post-purchase review (Croom \& Jones., 2005; Trkman \& McCormack., 2010). E-Procurement is critical to construction because it involves a number of partners on each project who all have the need for inventory management in order not to delay the project or to tie space and money on excess inventory while also complying with specifications and other variables (Pheng \& Meng, 1997). Beyond the obvious transaction cost savings and access to suppliers, e-Procurement can offer product standardization, quality assurance, inventory management and the opportunity to manage material flows down the value chain. The e-Procurement also automates the workflow of procurement/resource management processes, which reduces the cycle time of purchases, decreases stocking requirements, and lowers inventory management costs. Thus, there is a need to measure the usage of e-procurement in Malaysian construction, and its impact to contractors' performance, which represents the aim of this study to find a validated instrument measuring the usage and performance of the system.

\section{Materials and Method}

The data collection employed in this study is from a self-administered survey questionnaire. The questionnaire is adapted from two different studies: Vankatesh et al., (2012) and Norzaidi (2008). The questionnaire was adapted and customized to suit the field of this study and was distributed to the respondents who were responsible and in charge of the company's eprocurement that comprise of company officials - general manager, assistant general manager, project manager, site manager, engineer, and executive. The survey was composed from 5 constructs (after the demographical data concerning the respondents): The first four constructs were related to UTAUT model; first construct: Performance Expectancy (5 items using the scale of 7). Second construct: Effort Expectancy (5 items using the scale of 7). Third construct: Social Influence (5 items using the scale of 7). Fourth construct: Facilitating Condition ( 6 items using the scale of 7). Fifth construct: E-procurement usage (4 items using the scale of 7).

Taherdoost (2019) in his study suggests the use of seven-point rating scale and if there is a need to have respondents to be directed on one side, then he claims that six-point scale is the most suitable. Accordingly, this study applied the interval scale of 7, in which the respondents selected a statement among several statements from 1-7 which is considered to reflect the perceived quality of the subject. Number 1 stands for strongly disagree, while, number 7 stands for strongly agree. According to Awang et al. $(2010 ; 2012 ; 2014 ; 2015)$ and Awang et al. (2018), the researcher should apply a Likert Scale without a label because this measure would give an interval type of data that is continuous and fit the data presumption for parametric analysis. As per Awang $(2010 ; 2012 ; 2014 ; 2015)$ and Hoque et al. $(2017 ; 2018)$, if the analyst adjusted instruments from past studies and altered accordingly, at that point 
the scientist needs to direct both pre-test and pilot-test for these "changed items" so as to approve them before it tends to be utilized in the final study. Content validity, face validity, and criterion validity were done as a pre-test for this questionnaire, content validity was done through content experts, and face validity was done through English language experts, criterion validity was done through a statistical expert, after these validation tests were completed, the researcher distributed the instrument to 3 respondents, in order to gather their comments, and check the consistency in their responses.

After all the required changes according to pre-test results had been done, the researcher distributed the questionnaire to gather a minimum of 100 responses to be able to run the exploratory factor analysis (EFA) as according to many researchers for example: Awang (2010, 2012, 2014, 2015), Hoque et al. (2017, 2018), Noor et al. (2015), Awang et al. (2018) and Yahaya et al. (2018) claim that EFA should be done for each construct to explore changes in dimensionality of items from past studies due to changes in the characteristics of population from the past.

\section{Results and Discussion}

\section{The EFA for the First Construct: Performance Expectancy}

Performance Expectancy construct was measured by using 5 items namely pe1 till pe5 (Table 1). Every statement of items was measured using Interval Scale ranging between 1 and 7 , where 1 stands for strongly disagree and 7 stands for strongly agree. The mean score and standard deviation derived for every single item which measured the constructs are shown in Table 1.

Table 1: Mean and Standard Deviation for items in Performance Expectancy

\begin{tabular}{|c|l|c|c|}
\hline Items & \multicolumn{1}{|c|}{ Item statement } & Mean & Std. Deviation \\
\hline pe1 & I find e-procurement useful & 5.66 & 0.867 \\
\hline pe2 & $\begin{array}{l}\text { Using e-procurement increase my chance of achieving } \\
\text { things that are important to me }\end{array}$ & 5.70 & 0.936 \\
\hline pe3 & $\begin{array}{l}\text { Using e-procurement helps me accomplish things more } \\
\text { quickly }\end{array}$ & 5.56 & 0.938 \\
\hline pe4 & Using e-procurement increases my productivity & 5.58 & 0.936 \\
\hline pe5 & Overall, I would find e-procurement to be advantageous & 5.45 & 1.011 \\
\hline
\end{tabular}

EFA using Principal Component Analysis as an extraction method performed for these 5 items to measure performance expectancy of using e-procurement. The results in Table 2 shows Bartlett's Test of Sphericity which is Significant since it's $<0.05$. Kaiser-Meyer-Olkin Measure of Sampling Adequacy higher than 0.6 which is for the first construct 0.855, and this means that the sample size is adequate (Awang, 2010; 2012; 2014; 2015; Hoque et al., 2017; 2018; and Noor et al., 2015). Accordingly, the current data are acceptable.

Table 2: KMO and Bartlett's Test score

\begin{tabular}{|c|c|c|}
\hline \multicolumn{2}{|c|}{$\begin{array}{c}\text { Kaiser-Meyer-Olkin Measure of Sampling } \\
\text { Adequacy. }\end{array}$} & 0.855 \\
\hline \multirow{2}{*}{$\begin{array}{c}\text { Bartlett's Test of } \\
\text { Sphericity }\end{array}$} & Approx. Chi-Square & 460.532 \\
\cline { 2 - 3 } & Df & 10 \\
\cline { 2 - 3 } & Sig. & 0.000 \\
\hline
\end{tabular}

The scree plot in Figure 1 shows that only one component emerged from the EFA, accordingly all items in this construct will belong to one component.

Figure 1: Scree Plot for the first construct 


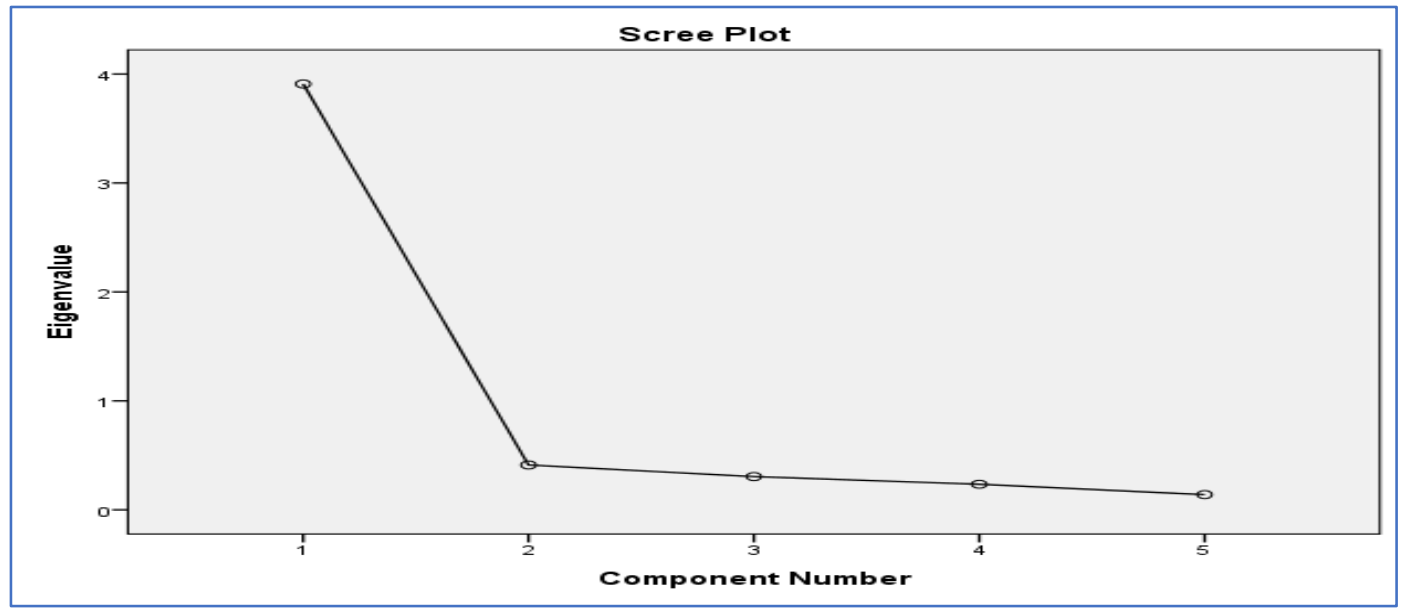

The results in Table 3 the components or dimension for each item is shown in this table, as it's clear all items are belonging to one component. The factor loading for every item should be $>0.6$ in order to be retained (Awang, 2010; 2012; Awang et al. (2018) and Yahaya et al., 2018). Thus all items will be retained.

Table 3: Factor Loading Matrix for Performance Expectancy

\begin{tabular}{|c|c|}
\hline Items & Factor Loading \\
\hline pe1 & 0.889 \\
\hline pe2 & 0.920 \\
\hline pe3 & 0.837 \\
\hline pe4 & 0.881 \\
\hline pe5 & 0.892 \\
\hline \multicolumn{2}{|l|}{$\begin{array}{l}\text { Extraction Method: Principal } \\
\text { Component Analysis. }\end{array}$} \\
\hline
\end{tabular}

The results in Table 4 show there are one dimension or component emerged from the EFA procedure based on the computed Eigenvalue $>1.0$. The total variance explained for measuring this construct is $78.183 \%$. The total variance explained is acceptable since it exceeds the minimum 60\% (Awang, 2010, 2012; 2014; 2015; Noor et al., 2015; Hoque et al., 2017; 2018; and Yahaya et al., 2018).

Table 4: Total variance explained

\begin{tabular}{|c|c|c|c|}
\hline \multirow{2}{*}{$\begin{array}{c}\text { Componen } \\
\mathrm{t}\end{array}$} & \multicolumn{3}{|c|}{ Extraction Sums of Squared Loadings } \\
\cline { 2 - 4 } & Total & $\begin{array}{c}\text { \% of } \\
\text { Variance }\end{array}$ & $\begin{array}{c}\text { Cumulative } \\
\%\end{array}$ \\
\hline 1 & 3.909 & 78.183 & 78.183 \\
\hline \multicolumn{4}{|c|}{ Extraction Method: Principal Component Analysis. } \\
\hline
\end{tabular}

The Internal Reliability for the Instrument Measuring Performance Expectancy

The last test that should be done is the internal reliability of each construct. As Table 5 shows that Cronbach's Alpha test is 0.929, higher than 0.7, which means that these items are reliable. 
Table 5: The internal reliability for performance expectancy

\begin{tabular}{|c|c|c|}
\hline Component & N of Items & $\begin{array}{c}\text { Cronbach } \\
\text { Alpha }\end{array}$ \\
\hline 1 & 5 & 0.929 \\
\hline
\end{tabular}

\section{The EFA for the Second Construct: Effort Expectancy}

This construct was measured using 5 items listed in Table 6 as ee1 to ee5, and each item was measured using Likert-scale of 7, where 1 stands for strongly disagree and 7 stands for strongly agree, the mean response, standard deviation and item statement, for each item, are listed in Table 6.

Table 6: Mean and Standard Deviation for items in Effort Expectancy

\begin{tabular}{|c|l|c|c|}
\hline Items & \multicolumn{1}{|c|}{ Item statement } & Mean & $\begin{array}{c}\text { Std. } \\
\text { Deviation }\end{array}$ \\
\hline ee1 & Learning how to use e-procurement is easy for me & 5.37 & 1.134 \\
\hline ee2 & My interaction with e-procurement is clear and understandable & 5.44 & 0.948 \\
\hline ee3 & I find e-procurement easy to use & 5.50 & 0.902 \\
\hline ee4 & It is easy for me to become skillful at using e-procurement & 5.47 & 0.930 \\
\hline ee5 & I find it easy to get e-procurement to do what I want it to do & 5.40 & 0.846 \\
\hline
\end{tabular}

EFA using principal component analysis as an extraction method performed for these 5 items to measure effort expectancy of using e-procurement. The results in Table 7 shows Bartlett's Test of Sphericity which is Significant since it's $<0.05$. Kaiser- Meyer-Olkin measure of sampling Adequacy higher than 0.6 which is for the 2 nd construct 0.847 , and this means that the sample size is adequate (Awang, 2010; 2012; 2014; 2015; Hoque et al., 2017, 2018; Noor et al., 2015). Accordingly, the current data are acceptable.

Table 7: KMO and Bartlett's Test score

\begin{tabular}{|l|c|c|}
\hline \multicolumn{2}{|l|}{$\begin{array}{l}\text { Kaiser-Meyer-Olkin Measure of Sampling } \\
\text { Adequacy. }\end{array}$} & 0.847 \\
\hline $\begin{array}{l}\text { Bartlett's Test of } \\
\text { Sphericity }\end{array}$ & Approx. Chi-Square & 422.524 \\
\cline { 2 - 3 } & Df & 10 \\
\cline { 2 - 3 } & Sig. & 0.000 \\
\hline
\end{tabular}

The scree plot in Figure 2 shows that only one component is emerged from the EFA, accordingly all items in this construct will belong to one component. 
Figure 2: The Scree Plot for the second construct

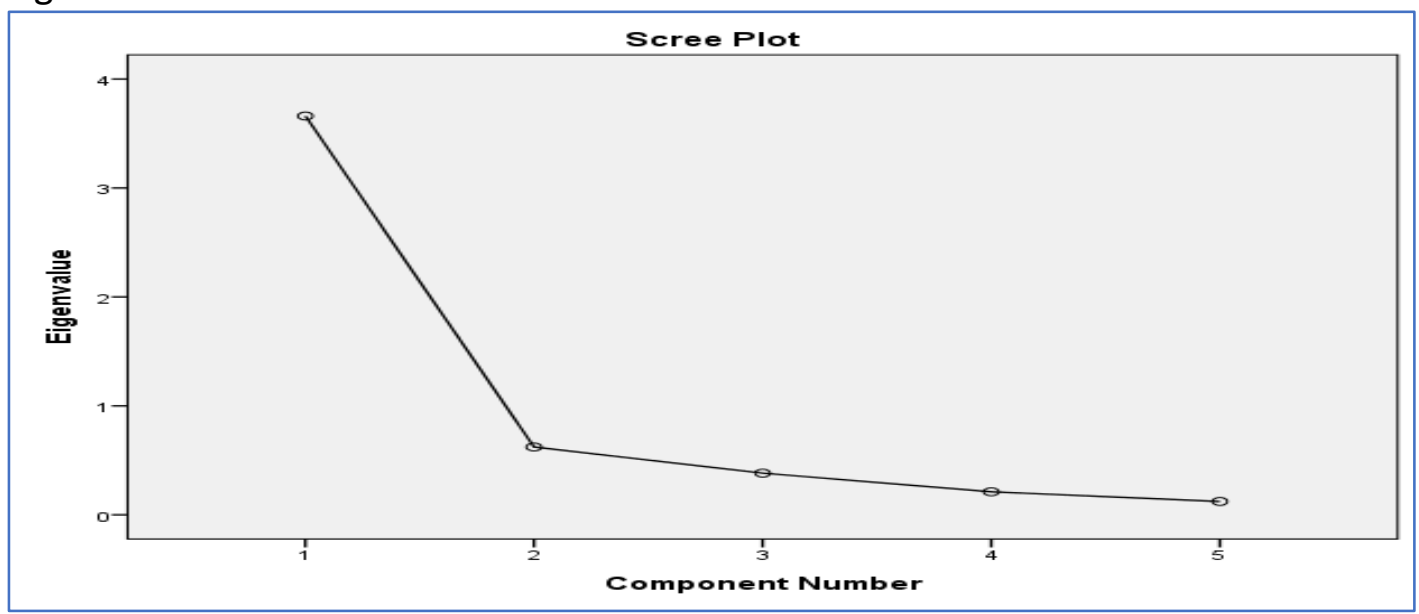

The results of the components or dimension for each item is shown in Table 8, as it's clear all items are belonging to one component. The factor loading for every item should be $>0.6$ in order to be retained (Awang, 2010; 2012; 2014; 2015; Awang et al., 2018 and Yahaya et al., 2018). Thus all items will be retained.

Table 8: Factor Loading Matrix for Effort Expectancy

\begin{tabular}{|c|c|}
\hline Items & Factor loading \\
\hline ee1 & 0.688 \\
\hline ee2 & 0.905 \\
\hline ee3 & 0.914 \\
\hline ee4 & 0.915 \\
\hline ee5 & 0.835 \\
\hline Extraction Method: Principal \\
Component Analysis. \\
\hline
\end{tabular}

The results in Table 9 show there are one dimension or component emerged from the EFA procedure based on the computed Eigenvalue $>1.0$. The total variance explained for measuring this construct is $73.217 \%$. The total variance explained is acceptable since it exceeds the minimum 60\% (Awang, 2010; 2012; 2014; 2015; Noor et al., 2015; Hoque et al., 2017, 2018; and Yahaya et al., 2018).

Table 9: Total variance explained

\begin{tabular}{|c|c|c|c|}
\hline \multirow{2}{*}{$\begin{array}{l}\text { Componen } \\
\mathrm{n}\end{array}$} & \multicolumn{3}{|c|}{ Extraction Sums of Squared Loadings } \\
\cline { 2 - 4 } & Total & $\begin{array}{c}\% \text { of } \\
\text { Variance }\end{array}$ & $\begin{array}{c}\text { Cumulative } \\
\%\end{array}$ \\
\hline 1 & 3.661 & 73.217 & 73.217 \\
\hline \multicolumn{4}{|c|}{ Extraction Method: Principal Component Analysis. } \\
\hline
\end{tabular}

The Internal Reliability for the Instrument Measuring Effort Expectancy

The last test that should be done is the internal reliability of each construct. As Table 10 shows that Cronbach's Alpha test is 0.898 , higher than 0.7 , which means that these items are reliable. 
Table 10: The internal reliability for effort expectancy

\begin{tabular}{|c|c|c|}
\hline Component & N of Items & $\begin{array}{c}\text { Cronbach } \\
\text { Alpha }\end{array}$ \\
\hline 1 & 5 & 0.898 \\
\hline
\end{tabular}

\section{The EFA for the Third Construct: Social Influence}

This construct was measured using 5 items listed in Table 11 as si1 to si5, and each item was measured using Likert-scale of 7, where 1 stands for strongly disagree and 7 stands for strongly agree, the mean response, standard deviation and item statement, for each item, are listed in Table 11.

Table 11: Mean and Standard Deviation for items in Social Influence

\begin{tabular}{|c|l|c|c|}
\hline Items & \multicolumn{1}{|c|}{ Item statement } & Mean & $\begin{array}{c}\text { Std. } \\
\text { Deviation }\end{array}$ \\
\hline si1 & $\begin{array}{l}\text { People who are important to me think that I should use e- } \\
\text { procurement }\end{array}$ & 5.58 & 0.772 \\
\hline si2 & $\begin{array}{l}\text { People who influence my behavior think that I should e- } \\
\text { procurement }\end{array}$ & 5.76 & 0.708 \\
\hline si3 & $\begin{array}{l}\text { People whose opinions that I value prefer that I use e- } \\
\text { procurement }\end{array}$ & 5.30 & 0.848 \\
\hline si4 & $\begin{array}{l}\text { Friend's suggestion and recommendation will affect my decision } \\
\text { to use e-procurement }\end{array}$ & 5.65 & 0.750 \\
\hline si5 & $\begin{array}{l}\text { I would use e-procurement because the proportion of my } \\
\text { friends use it }\end{array}$ & 5.17 & 1.070 \\
\hline
\end{tabular}

EFA using principal component analysis as an extraction method performed for these 5 items to measure social influence of using e-procurement. The results in Table 12 shows Bartlett's Test of Sphericity which is significant since it's $<0.05$. Kaiser-Meyer-Olkin measure of sampling Adequacy higher than 0.6 which is for the third construct 0.787 , and this means that the sample size is adequate (Awang, 2010; 2012; 2014; 2015; Hoque et al., 2017, 2018; Noor et al., 2015). Accordingly, the current data are acceptable.

Table 12: KMO and Bartlett's Test score

\begin{tabular}{|l|c|c|}
\hline \multicolumn{2}{|l|}{$\begin{array}{l}\text { Kaiser-Meyer-Olkin Measure of Sampling } \\
\text { Adequacy. }\end{array}$} & 0.787 \\
\hline $\begin{array}{l}\text { Bartlett's Test of } \\
\text { Sphericity }\end{array}$ & Approx. Chi-Square & 209.178 \\
\cline { 2 - 3 } & Df & 10 \\
\cline { 2 - 3 } & Sig. & 0.000 \\
\hline
\end{tabular}

The scree plot in Figure 3 shows that only one component is emerged from the EFA, accordingly all items in this construct will belong to one component.

Figure 3: The Scree Plot for the third construct 


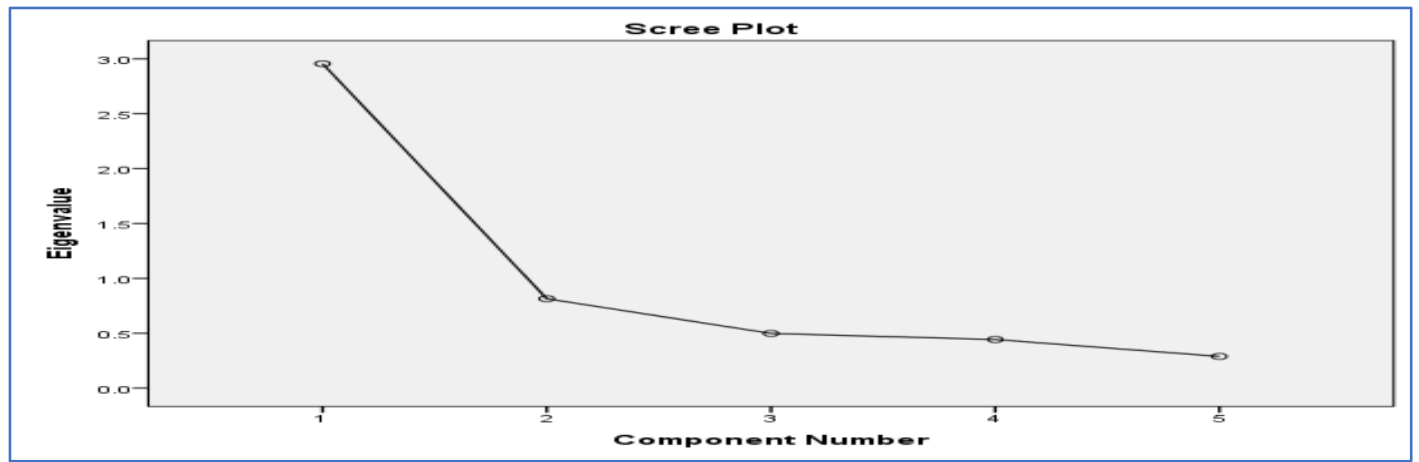

The results in Table 13, the components or dimension for each item is shown in this table, as it's clear all items are belonging to one component. The factor loading for every item should be >0.6 in order to be retained (Awang, 2010; 2012; 2014; 2015; Awang et al., 2018 and Yahaya et al., 2018). Thus all items will be retained.

Table 13: Factor Loading Matrix for Social Influence

\begin{tabular}{|c|c|}
\hline Items & Factor loading \\
\hline si 1 & 0.754 \\
\hline si2 & 0.823 \\
\hline si3 & 0.796 \\
\hline si 4 & 0.811 \\
\hline si5 & 0.646 \\
\hline $\begin{array}{l}\text { Extraction Method: Principal } \\
\text { Component Analysis. }\end{array}$ \\
\hline
\end{tabular}

The results in Table 14 show there are one dimension or component emerged from the EFA procedure based on the computed Eigenvalue $>1.0$. The total variance explained for measuring this construct is $62.123 \%$. The total variance explained is acceptable since it exceeds the minimum 60\% (Awang, 2010; 2012; 2014; 2015; Noor et al., 2015; Hoque et al., 2017, 2018; and Yahaya et al., 2018).

Table 14: Total variance explained

\begin{tabular}{|c|c|c|c|}
\hline \multirow{2}{*}{$\begin{array}{l}\text { Componen } \\
\mathrm{n}\end{array}$} & \multicolumn{3}{|c|}{ Extraction Sums of Squared Loadings } \\
\cline { 2 - 4 } & Total & $\begin{array}{c}\text { \% of } \\
\text { Variance }\end{array}$ & $\begin{array}{c}\text { Cumulative } \\
\%\end{array}$ \\
\hline 1 & 2.956 & 62.123 & 62.123 \\
\hline \multicolumn{4}{|c|}{ Extraction Method: Principal Component Analysis. } \\
\hline
\end{tabular}

\section{The Internal Reliability for the Instrument measuring Social Influence}

The last test that should be done is the internal reliability of each construct. As Table 15 shows that Cronbach's Alpha test is 0.809 , higher than 0.7, which means that these items are reliable. 
Table 15: The internal reliability for social influence

\begin{tabular}{|c|c|c|}
\hline Component & N of Items & $\begin{array}{c}\text { Cronbach } \\
\text { Alpha }\end{array}$ \\
\hline 1 & 5 & 0.809 \\
\hline
\end{tabular}

\section{The EFA for the Fourth Construct: Facilitating Condition}

This construct was measured using 5 items listed in Table 16 as fc1 to fc5, and each item was measured using Likert-scale of 7, where 1 stands for strongly disagree and 7 stands for strongly agree, the mean response, standard deviation and item statement, for each item, are listed in Table 16.

Table 16: Mean and Standard Deviation for items in Facilitating Condition

\begin{tabular}{|c|l|c|c|}
\hline Items & \multicolumn{1}{|c|}{ Item statement } & Mean & $\begin{array}{c}\text { Std. } \\
\text { Deviation }\end{array}$ \\
\hline fc1 & I have the resources necessary to e-procurement & 5.59 & 0.760 \\
\hline fc2 & I have the knowledge necessary to use e-procurement & 5.69 & 0.742 \\
\hline fc3 & E-procurement is compatible with other technologies I use & 5.53 & 0.729 \\
\hline fc4 & $\begin{array}{l}\text { I can get help from others when I have difficulties using e- } \\
\text { procurement }\end{array}$ & 5.51 & 0.799 \\
\hline fc5 & Using e-procurement is entirely within my control & 5.65 & 0.761 \\
\hline
\end{tabular}

EFA using principal component analysis as an extraction method performed for these 5 items to measure facilitating condition of using e-procurement. The results in Table 17 shows Bartlett's Test of Sphericity which is Significant since it's $<0.05$. Kaiser- Meyer-Olkin measure of sampling Adequacy higher than 0.6 which is for the fourth construct 0.810 , and this means that the sample size is adequate (Awang, 2010; 2012; 2014; 2015; Hoque et al., 2017, 2018; Noor et al., 2015). Accordingly, the current data are acceptable.

Table 17: KMO and Bartlett's Test score

\begin{tabular}{|l|c|c|}
\hline \multicolumn{2}{|l|}{$\begin{array}{l}\text { Kaiser-Meyer-Olkin Measure of Sampling } \\
\text { Adequacy. }\end{array}$} & 0.810 \\
\hline $\begin{array}{l}\text { Bartlett's Test of } \\
\text { Sphericity }\end{array}$ & Approx. Chi-Square & 322.654 \\
\cline { 2 - 3 } & Df & 10 \\
\cline { 2 - 3 } & Sig. & 0.000 \\
\hline
\end{tabular}

The scree plot in Figure 4 shows that only one component is emerged from the EFA, accordingly all items in this construct will belong to one component. 
Figure 4: The Scree Plot for the fourth construct

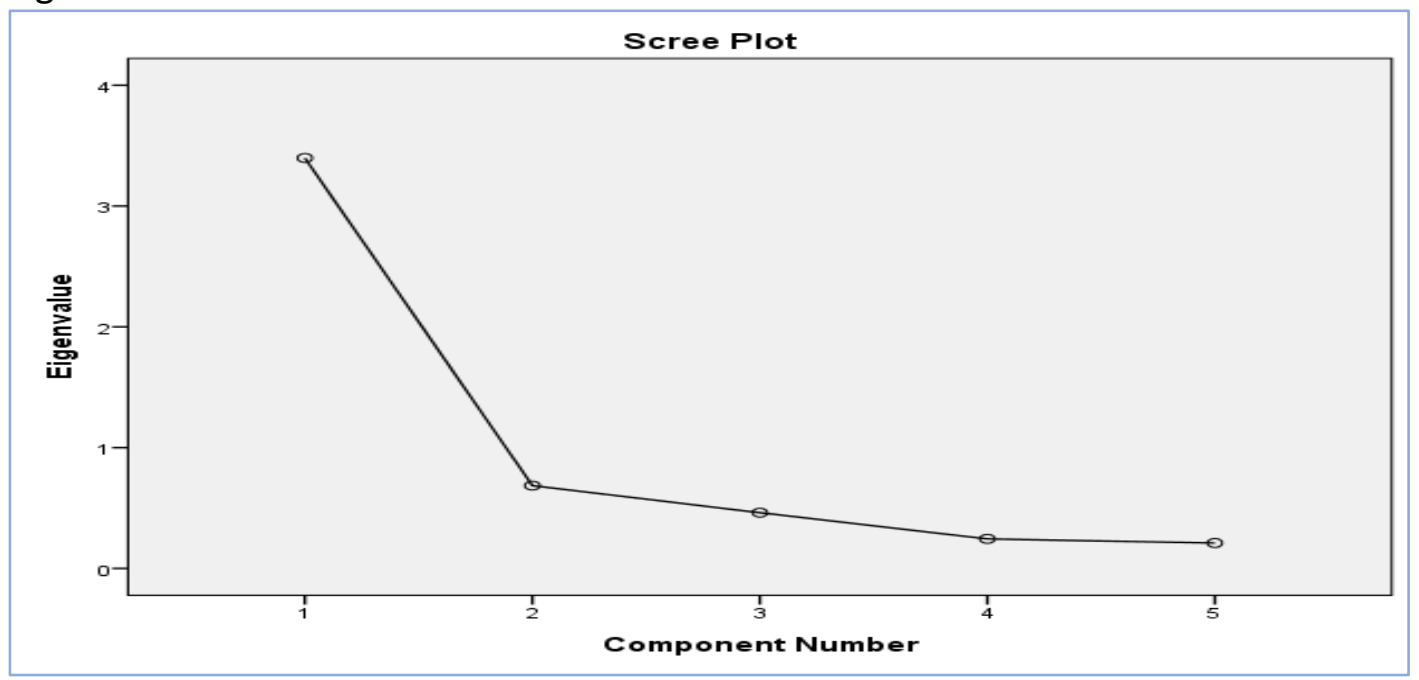

The results in Table 18 the components or dimension for each item is shown in this table, as it's clear all items are belonging to one component. The factor loading for every item should be >0.6 in order to be retained (Awang, 2010; 2012; 2014; 2015; Awang et al., 2018 and Yahaya et al., 2018). Thus, all items will be retained.

Table 18: Factor Loading Matrix for Facilitating Condition

\begin{tabular}{|c|c|}
\hline Items & Factor loading \\
\hline $\mathrm{fc} 1$ & 0.881 \\
\hline $\mathrm{fc} 2$ & 0.823 \\
\hline $\mathrm{fc} 3$ & 0.765 \\
\hline $\mathrm{fc} 4$ & 0.845 \\
\hline $\mathrm{fc5}$ & 0.803 \\
\hline Extraction Method: Principal \\
Component Analysis. \\
\hline
\end{tabular}

The results in Table 19 show there are one dimension or component emerged from the EFA procedure based on the computed Eigenvalue $>1.0$. The total variance explained for measuring this construct is $67.955 \%$. The total variance explained is acceptable since it exceeds the minimum 60\% (Awang, 2010; 2012; 2014; 2015; Noor et al., 2015; Hoque et al., 2017, 2018; and Yahaya et al., 2018).

Table 19: Total variance explained

\begin{tabular}{|l|c|c|c|}
\hline \multirow{2}{*}{$\begin{array}{l}\text { Componen } \\
\mathrm{t}\end{array}$} & \multicolumn{3}{|c|}{ Extraction Sums of Squared Loadings } \\
\cline { 2 - 4 } & Total & $\begin{array}{c}\text { \% of } \\
\text { Variance }\end{array}$ & $\begin{array}{c}\text { Cumulative } \\
\%\end{array}$ \\
\hline 1 & 3.398 & 67.955 & 67.955 \\
\hline \multicolumn{4}{|c|}{ Extraction Method: Principal Component Analysis. } \\
\hline
\end{tabular}

The internal reliability for the instrument measuring Facilitating Condition

The last test that should be done is the internal reliability of each construct. As Table 20 shows that Cronbach's Alpha test is 0.880 , higher than 0.7 , which means that these items are reliable. 
Table 20: The internal reliability for facilitating condition

\begin{tabular}{|c|c|c|}
\hline Component & N of Items & $\begin{array}{c}\text { Cronbach } \\
\text { Alpha }\end{array}$ \\
\hline 1 & 5 & 0.880 \\
\hline
\end{tabular}

\section{The EFA for the Fifth Construct: e-procurement Usage}

This construct was measured using 4 items listed in Table 21 as pu1 to pu5, and each item was measured using Likert-scale of 7, where 1 stands for strongly disagree and 7 stands for strongly agree, the mean response, standard deviation and item statement, for each item, are listed in Table 21.

Table 21: Mean and Standard Deviation for items in e-procurement Usage

\begin{tabular}{|c|l|c|c|}
\hline Items & \multicolumn{1}{|c|}{ Item statement } & Mean & $\begin{array}{c}\text { Std. } \\
\text { Deviation }\end{array}$ \\
\hline pu1 & I use e-procurement a lot to do my work & 5.97 & 0.648 \\
\hline pu2 & I use e-procurement whenever possible to do my work & 6.03 & 0.648 \\
\hline pu3 & I use e-procurement frequently to do my work & 6.06 & 0.611 \\
\hline pu4 & I use e-procurement whenever appropriate to do my work & 5.84 & 0.801 \\
\hline
\end{tabular}

EFA using principal component analysis as an extraction method performed for these 4 items to measure e-procurement usage of using e-procurement. The results in Table 22 shows Bartlett's Test of Sphericity which is Significant since it's $<0.05$. Kaiser- Meyer-Olkin measure of sampling Adequacy higher than 0.6 which is for the fifth construct 0.793 , and this means that the sample size is adequate (Awang, 2010; 2012; 2014; 2015; Hoque et al., 2017, 2018; Noor et al., 2015). Accordingly, the current data are acceptable.

Table 22: KMO and Bartlett's Test score

\begin{tabular}{|l|c|c|}
\hline \multicolumn{2}{|l|}{$\begin{array}{l}\text { Kaiser-Meyer-Olkin Measure of Sampling } \\
\text { Adequacy. }\end{array}$} & 0.793 \\
\hline $\begin{array}{l}\text { Bartlett's Test of } \\
\text { Sphericity }\end{array}$ & Approx. Chi-Square & 223.678 \\
\cline { 2 - 3 } & Df & 6 \\
\cline { 2 - 3 } & Sig. & 0.000 \\
\hline
\end{tabular}

The scree plot in Figure 5 shows that only one component is emerged from the EFA, accordingly all items in this construct will belong to one component.

Figure 5: The Scree Plot for the fifth construct

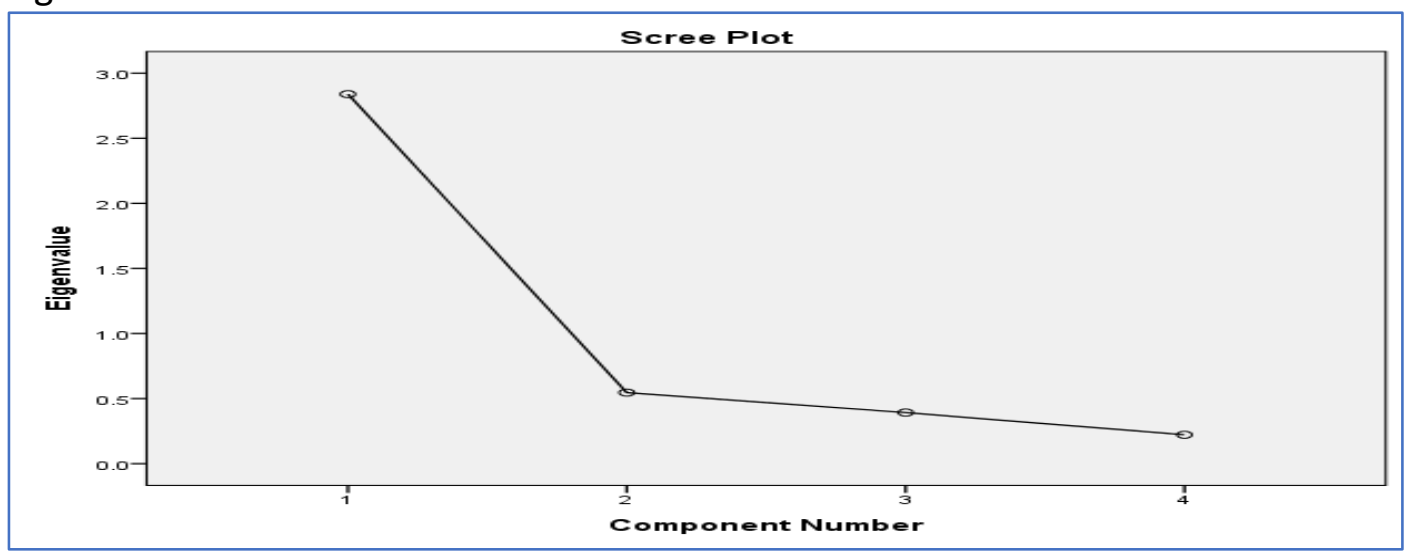


The results in Table 23 the components or dimension for each item is shown in this table, as it's clear all items are belonging to one component. The factor loading for every item should be $>0.6$ in order to be retained (Awang, 2010; 2012; 2014; 2015; Awang et al., 2018 and Yahaya et al., 2018). Thus all items will be retained.

Table 23: Factor Loading Matrix for e-procurement Usage

\begin{tabular}{|c|c|}
\hline Items & Factor loading \\
\hline pu1 & 0.820 \\
\hline pu2 & 0.916 \\
\hline pu3 & 0.855 \\
\hline pu4 & 0.773 \\
\hline \multicolumn{2}{|c|}{$\begin{array}{l}\text { Extraction Method: Principal } \\
\text { Component Analysis. }\end{array}$} \\
\hline
\end{tabular}

The results in Table 24 show there are one dimension or component emerged from the EFA procedure based on the computed Eigenvalue $>1.0$. The total variance explained for measuring this construct is $70.973 \%$. The total variance explained is acceptable since it exceeds the minimum 60\% (Awang, 2010; 2012; 2014; 2015; Noor et al., 2015; Hoque et al., 2017, 2018; and Yahaya et al., 2018; Khalid, 2020).

Table 24: Total variance explained

\begin{tabular}{|c|c|c|c|}
\hline \multirow{2}{*}{\begin{tabular}{l} 
Componen \\
\cline { 2 - 4 }
\end{tabular}} & Extraction Sums of Squared Loadings \\
\cline { 2 - 4 } & Total & $\begin{array}{c}\% \text { of } \\
\text { Variance }\end{array}$ & $\begin{array}{c}\text { Cumulative } \\
\%\end{array}$ \\
\hline 1 & 2.839 & 70.973 & 70.973 \\
\hline \multicolumn{4}{|c|}{ Extraction Method: Principal Component Analysis. } \\
\hline
\end{tabular}

The internal reliability for the instrument measuring e-procurement Usage

The last test that should be done is the internal reliability of each construct. As Table 20 shows that Cronbach's Alpha test is 0.880 , higher than 0.7, which means that these items are reliable.

Table 25: The internal reliability for facilitating condition

\begin{tabular}{|c|c|c|}
\hline Component & N of Items & $\begin{array}{c}\text { Cronbach } \\
\text { Alpha }\end{array}$ \\
\hline 1 & 4 & 0.854 \\
\hline
\end{tabular}

\section{Conclusion}

The current research adds a remarkable contribution to the measurement of the 5 constructs, mainly in the e-procurement context. The results show that every of the five constructs have one component or dimension, the factor loading for every item exceeds the minimum threshold of 0.6, with high Cronbach's Alpha value, meet Bartlet Test achievements (significant) for all the constructs, Kaiser-Meyer-Olkin Measure of Sampling Adequacy was higher than 0.6 for all the constructs, and factor loading exceeds the minimum threshold of 0.6. Hence, this study found a valid and reliable instrument for measuring the usage of eprocurement to Malaysian contractors'. Therefore, this instrument can be used to measure the usage of e-procurement in the targeted organizations in this study. 
However, it is recommended during field study that some precautions need to be done to ensure that the data collection are free from response bias and common method variance and therefore, would generate significant findings.

\section{References}

Awang, Z. (2010), Research Methodology for Business and Social Sciences. Malaysia: Universiti Teknologi MARA.

Awang, Z. (2012), Research Methodology and Data Analysis. Malaysia: Penerbit Universiti Teknologi MARA Press.

Awang, Z. (2014), A Handbook on SEM for Academicians and Practitioners: The Step by Step Practical Guides for the Beginners. Bandar Baru Bangi: MPWS Rich Resource.

Awang, Z. (2015), SEM Made Simple: A Gentle Approach to Learning Structural Equation Modelling. Bandar Baru Bangi: MPWS Rich Resources.

Awang, Z., Afthanorhan, W. M. A., Asri, M. A. M. (2015), Parametric and non-parametric approach in structural equation modeling (SEM): The application of bootstrapping. Modern Applied Science, 9(9), 58.

Awang, Z., Lim, S. H., Zainudin, N. F. S. (2018), Pendekatan Mudah SEM-Structural Equation Modelling. Bandar Baru Bangi: MPWS Rich Resources.

Croom, S. R., and Jones, A. B. (2005), Key issues in e-procurement: Procurement implementation and operation in the public sector. Journal of Public Procurement, Vol. 5(3), pp. 367-387.

Hoque, A. S. M., Awang, Z., Jusoff, K., Salleh, F., Muda, H. (2017), Social business efficiency: Instrument development and validation procedure using structural equation modelling. International Business Management, 11(1), 222-231.

Hoque, A. S. M., Siddiqui, B. A., Awang, Z. B., Baharu, S. M. A. (2018), Explortory factor analysis of entrepreneurial orientation in the context of Bangladesh small and medium entreprises (SMES). European Journal of Management and Marketing Studies, 3, 81-94.

Noor, N. M., Aziz, A. A., Mostapa, M. R., Awang, Z. (2015), Validation of the malay version of the inventory of functional status after childbirth questionnaire. BioMed Research International, 2015, 1-10.

Norzaidi, M. D. (2008), "Factors determining intranet usage: An empirical study of middle managers in the Malaysian port industry." Ph.D. dissertation, MMU, Malaysia.

Khalid, N. (2020). Artificial intelligence learning and entrepreneurial performance among university students: evidence from malaysian higher educational institutions. Journal of Intelligent \& Fuzzy Systems, (Preprint), 1-19.

Pheng, L. S., and Meng, C. Y. (1997). Managing productivity in construction: JIT Operations and Measurements Press: Vermont. Athenaeum.

Taherdoost, H. (2019). What Is the Best Response Scale for Survey and Questionnaire Design; Review of Different Lengths of Rating Scale / Attitude Scale / Likert Scale. International Journal of Academic Research in Management (IJARM), Volume 8, Issue 1, 2019, ISSN: 2296-1747, ffhal-02557308

Trkman, P., and McCormack, K. (2010). Estimating the benefits and risks of implementing eprocurement, IEEE Transaction on Engineering Management, Vol. 57(2), pp. 338-349.

Venkatesh, V., Thong, J. Y. L., \& Xu, X. (2012). Consumer acceptance and use of information technology: Extending the unified theory of acceptance and use of technology. MIS Quarterly, 36(1), 157-178. 
Yahaya, T., Idris, K., Suandi, T., Ismail, I. (2018), Adapting instruments and modifying statements: The confirmation method for the inventory and model for information sharing behavior using social media. Management Science Letters, 8(5), 271-282. 